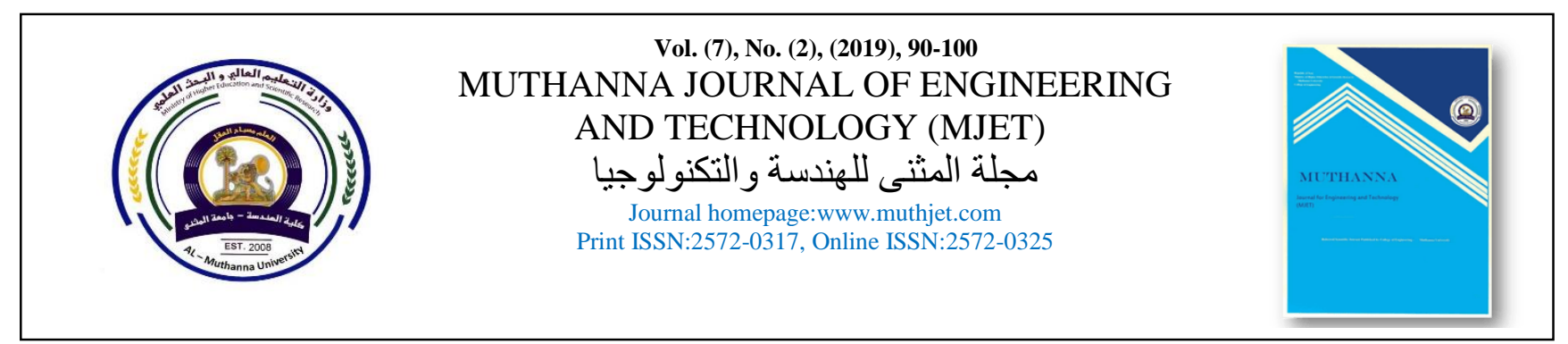

\title{
Practical study on the electrochemical simultaneous removal of copper and cadmium from simulated wastewater using rotating tubular packed bed cathode
}

\author{
Jenan H. Hemeidan a , Ali H. Abbar ${ }^{\text {a* }}$

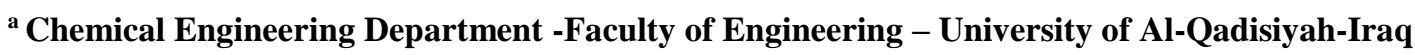

\section{ARTICLE INFO}

Received: 11/09/2019

Accepted: 28/10/2019

\section{Keywords}

Copper, Cadmium,

Three-dimensional electrodes, Rotating cylinder electrode, Woven screens,

\begin{abstract}
ABSTRA CT
The simultaneous removal of copper and cadmium from a simulated wastewater using rotating tubular packed bed of woven screens electrode was investigated. The effect of weight present of each metal on the removal efficiency and current efficiency was studied. The experiments were carried out at current $1.5 \mathrm{~A}$, rotation speed $450 \mathrm{rpm}, \mathrm{pH}=2$, and total concentration of metals $(300 \mathrm{ppm})$ at different weight percent of each metal. The results showed that the removal efficiency of copper increased from $93.5 \%$ to $99.33 \%$ as its weight percent increased from $20 \%$ to $100 \%$. In a similar fashion, the removal efficiency of cadmium increased from $80 \%$ to $90 \%$ as its weight percent increased from $20 \%$ to $100 \%$. The results confirmed that the removal efficiency of any metals decreased in the presence of other metal. The results established that current efficiency for the simultaneous removal of copper and cadmium decreased with increasing of electrolysis time and $\mathrm{Cd}$ percent weight or decreasing of $\mathrm{Cu}$ weight percent. Current efficiency is higher at the initial stage of electrolysis and then declined with increasing time for all weight percent of metals.
\end{abstract}

\footnotetext{
* Corresponding author.

E-mail address: hussainjenan@yahoo.com

C2019 AL-Muthanna University. All rights reserved.

DOI: $10.52113 / 3 / \mathrm{mjet} / 2019-7 / 90-100$
} 


\section{Introduction}

One of the main worldwide environmental problems is the contamination of water by toxic heavy metals existing in the industrial wastewaters. Rapid industrialization has extremely increased the release of such toxic metals to water streams. Heavy metals are non-biodegradable as organic wastes and they can be accumulated in living tissues, causing numerous disorders and diseases; therefore wastewater involving heavy metals should be treated to remove these toxic metals before discharge [1]. Heavy metals such as cadmium and copper are the most common pollutants found in industrial effluents which are extremely toxic in relatively low dosages [2]. Copper is introduced into water bodies from electroplating, mechanical manufacturing industry, light industry and architecture. copper is essential in a trace amount for the body but it causes serious lesions in the central nervous system and even permanent damage especially for children when existing at high doses [3]. Cadmium enters into water bodies from cadmium-nickel batteries, smelting, mining, metal plating, pigments, phosphate fertilizers, stabilizers, alloy industries and sewage sludge. The destructive effects of cadmium involve many of severe and chronic disorders such as "itai-itai" disease, emphysema, renal damage, testicular atrophy and hypertension [4]. Hence, removal of copper and cadmium from wastewater is importance. Besides their simultaneous removal offers a cost-effective solution because of avoiding the repeated one-byone removal of pollutants leading to an attractive low-cost strategy [5].

Various technologies have been developed over the years to remove copper and cadmium such as reduction and precipitation [6], adsorption on activated carbon [7;8], flotation, coagulation [9], reverse osmosis, ion exchange, and electro-dialysis [10]. Many of them are restricted due to their disadvantage and economic constraints, for example production of the sludge in the precipitation method leads to challenges in management, treating and landfilling of the solid sludge [11]. In the other hand, the high capital and regeneration costs of the materials limits the largescale use of activated carbon for metals removal. Therefore, there is a need for the development of a low cost process to remove heavy metals economically.

Electrochemical approach (cathodic deposition) as a dramatic alternative to the well-known techniques offers electrochemical reactors that used electrochemical reduction reactions as a principal approach for removal of heavy metals ions from wastewater, where these metals are electrodeposited on the electrode surface as a solid metallic deposits when the effluents flow through the electrochemical reactor hence the possibility of reusing them from the main process. Herein, adding of chemicals is not required leading to facilitate of water reuse [12; $13 ; 14]$. The electrochemical method is considered as a clean, environmentally engaging technology since the major reaction reagent is the electron. Economically, electrochemical method is valuable due to the lower energy consumption in comparing with the well-known techniques $[\mathbf{1 3} ; \mathbf{1 5}]$. Besides, applying the automatization in controlling of current during the electrodeposition process results in lowering the workload requirements [16].

Researchers with various electrochemical reactor designs have been used for the electrochemical removal of copper and cadmium from simulated or real solutions with different degrees of achievements and enhancements $[17 ; 18 ; 19 ; 20 ; 21 ; 22 ; 23 ; 24]$. To ensure efficient applying of electrochemical method for diluted effluents treatment, the electrochemical reactors should have as possible as higher value of the product of mass-transfer coefficient and specific surface area of the cathode which in turn improve the space time yield of the reactor. This aim can be accomplished by using packed bed rotating cylinder electrodes which have been recognized as an efficient type of electrochemical reactors that used for heavy metals removal [25]. This kind of electrochemical reactor has characteristics not engaged by other reactors for instance the possibility of operating at continuous mode and a simple operable compact design [26;25]. Tubular packed bed of woven screens cylinder electrode is one of the packed bed rotating cylinders that didn't used before as a packed bed rotating cylinder electrode for heavy metals removal [27]. In this configuration, the cathode was constructed from a number of coaxial closely packed layers of vertical screen cylinders. This type of rotating cylinder electrode has high turbulence-promoting action due to its woven structure which has high surface area per unit volume [27].

The aim of present work is to study the simultaneous removal of copper and cadmium from a simulated waste water using a modified design of tubular packed bed of woven screens cylinder electrode. The modified design is composed of a stainless steel perforated hallow cylinder used as a current feeder over which continuous layers of stainless steel screens winded around it and bounded by two sleeves. This new configuration help in using high rotation speed hence higher turbulence action can be achieved. Besides, this configuration could be easily scaled-up to the industrial scale. The effects of weight percent of each metals on the removal efficiency and current efficiency of the electrochemical reactor were investigated.

\section{Experimental work}

The electrolysis runs were performed in a $0.5 \mathrm{~L}$ Perspex electrolytic cell. The cathode (working electrode) was a rotating tubular packed bed 
electrode composed of 316 stainless steel woven screens wrapped around a stainless hallow cylinder acting as a current feeder. The hallow cylinder current feeder was opened at the bottom and closed at the upper. It is perforated with a total of (15) holes with diameter $(6 \mathrm{~mm})$ distributed uniformly on the lateral surface of the cylinder. The cathode feeder has outer diameter of $(35 \mathrm{~mm})$, inner diameter $(28 \mathrm{~mm})$ with total length $(60 \mathrm{~mm})$. The lower part of this feeder is jointed with a Teflon sleeve has diameter $(50 \mathrm{~mm})$ and height $(12 \mathrm{~mm})$, while the upper part is jointed with a Teflon sleeve has $(17 \mathrm{~mm}$ height and $50 \mathrm{~mm}$ diameter) in order to fix the wrapped woven screens sheets on the current feeder. The cathode current feeder was attached to the shaft of variable speed motor via a stainless steel rod (7 mm diameter and $100 \mathrm{~mm}$ length) fixed on the cathode feeder. The cathode has an apparent surface area of $(117.81 \mathrm{~cm} 2)(50 \mathrm{~mm}$ diameter and $60 \mathrm{~mm}$ long). Outer graphite cylinder having dimensions $(90 \mathrm{~mm}$ inside diameter, $5 \mathrm{~mm}$ thickness , and $90 \mathrm{~mm}$ long), and central graphite rod having dimensions (60 mm length and $20 \mathrm{~mm}$ diameter) were used as counter electrode (anode). For ensuring a uniform primary current distribution, the three electrodes (cathode, outside anode, and inside anode) were concentric in the cell body. Figure 1 displays the schematic diagram of the experimental setup.

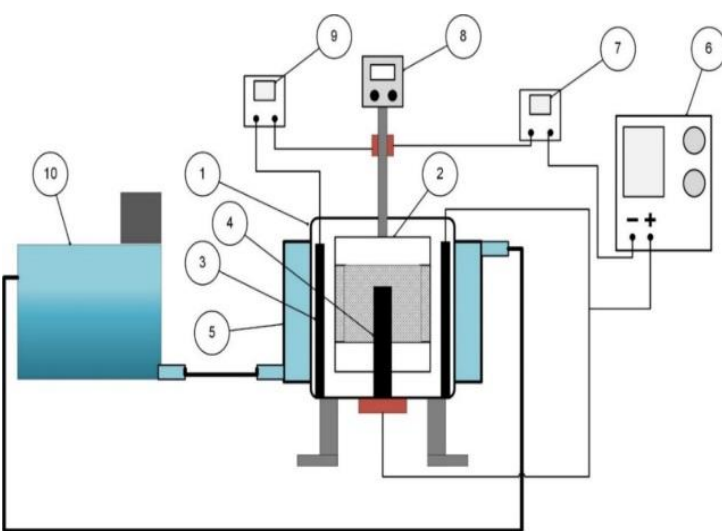

Figure 1: The schematic diagram of the experimental setup:1) cell body, 2) cathode, 3) outside anode, 4) inside anode, 5) jacket, 6) power supply, 7) Ammeter, 8) electrical motor,9) voltmeter,10) water bath circulator

Before starting any run, cathode was washed with (1M) nitric acid solution in an ultrasound cleaner for removing copper and cadmium deposits of the previous run then rinsed again thoroughly by double-distilled water. The galvanostatic mixed metals deposition was conducted by using power Supply-model TP-1305EC, 30V / 5A. Stainless steel screen having mesh numbers 30 was used. The properties of this screen are presented in Table 1. Screen porosity $(\varepsilon)$ was evaluated by determining the screen weight /area density and applying Eq.(1), then screen specific surface area(s) was computed based on Eq.2 (Sioda, 1976):

$$
\begin{aligned}
& \varepsilon=1-\frac{m_{s}}{\rho_{s} l a_{s}} \\
& s=(1-\varepsilon) r
\end{aligned}
$$

Where (r) is the surface to volume ratio of the screen wire equal to $(4 / \mathrm{d}),\left(\mathrm{m}_{\mathrm{s}} / \mathrm{a}_{\mathrm{s}}\right)$ is the weight /area density, $\left(\rho_{\mathrm{s}}\right)$ is the density of stainless steel 316 -AISI equal to $8.027 \mathrm{gm} / \mathrm{cm}^{3}$ [29], $(l)$ is the screen thickness equal to $2 \mathrm{~d}$.

The woven type of the screen was identified by using Olympus BX51M with DP70 digital camera system whereas a digital caliper was used to measure wire diameter $(\mathrm{d})$.

Table 1: Properties of Screen with Mesh number (30 wire/inch)

\begin{tabular}{cc}
\hline Property & Value \\
\hline Type of woven & Plain square \\
$\mathrm{d}, \mathrm{cm}$ & 0.030 \\
$\left(\mathrm{~m}_{\mathrm{s}} / \mathrm{a}_{\mathrm{s}}\right), \mathrm{g} / \mathrm{cm}^{2}$ & 0.1237 \\
$\boldsymbol{\varepsilon}$ & 0.7146 \\
$\boldsymbol{s}, \mathrm{cm}^{-1}$ & 38.06 \\
\hline
\end{tabular}

Copper sulfate $\left(\mathrm{CuSO}_{4}\right)$ and cadmium sulfate $\left(3 \mathrm{CdSO}_{4} .8 \mathrm{H}_{2} \mathrm{O}\right)$ were used as a source of copper ion and cadmium ion respectively while sodium sulfate $\left(\mathrm{Na}_{2} \mathrm{SO}_{4}\right)$ was used as a supporting electrolyte. All chemicals were of reagent grade. Doubly distilled water was used for preparing electrolytic solutions containing copper and cadmium ions dissolved in $0.5 \mathrm{M} \mathrm{Na} \mathrm{SO}_{4}$ at a total concentration of $300 \mathrm{ppm}$ for different weight percent for these metals, Table 2 shows these weight percent.

Table 2: Weight percent of copper and cadmium with a total concentration of $300 \mathrm{ppm}$

\begin{tabular}{ccc}
\hline $\begin{array}{c}\text { Weight percent } \\
(\%) \text { of copper }\end{array}$ & $\begin{array}{c}\text { Copper } \\
\text { conc. }(\mathbf{p p m})\end{array}$ & $\begin{array}{c}\text { Cadmium } \\
\text { conc.(ppm) }\end{array}$ \\
\hline 0 & 0 & 300 \\
20 & 60 & 240 \\
40 & 120 & 180 \\
60 & 180 & 120 \\
80 & 240 & 60 \\
100 & 300 & 0 \\
\hline
\end{tabular}

The final $\mathrm{pH}$ of electrolytic solutions was 2 adjusted by using (1 M) $\mathrm{H} 2 \mathrm{SO} 4$ or $(1 \mathrm{M}) \mathrm{NaOH}$. Indeed using $\mathrm{pH}$ value higher than 2 will give higher removal of copper by electrodeposition. However, it is difficult to use $\mathrm{pH}$ higher than 2 since copper could be precipitated as hydroxide if the solution $\mathrm{pH}$ is greater than 2 as approved by theoretical solubility of copper hydroxide diagram [30], hence most of previous works on copper removal operated at $\mathrm{pH}=2[31 ; 32]$.

All runs were proceeded at current of $1.5 \mathrm{~A}$, rotation speed of $450 \mathrm{rpm}$, and total initial 
concentration of $300 \mathrm{ppm}$ The selected values of these operation variables represent the midpoint of the studied range of these variables in the BoxBehnken experimental design adopted in our previous work for copper removal using this rotating electrode where copper removal efficiency higher than $97 \%$ was obtained [33]. Our previous results showed that using current higher than $1.5 \mathrm{~A}$ resulted in a slightly increase in removal efficiency with a large drops in current efficiency. Also using rotation speed higher than 450rpm gave a little enhancement in removal efficiency. The experiments were performed at constant temperature of $30 \pm 1^{\circ} \mathrm{C}$.

The removal efficiency (RE, \%) was computed according to the following equation [24]:

$R E=\frac{C_{i}-C_{f}}{C_{i}} \times 100$

Where, $\mathrm{C}_{\mathrm{i}}$ is the initial copper or cadmium concentration, $\mathrm{C}_{\mathrm{f}}$ is the final copper or cadmium concentration after an interval of time $(\Delta t)$.

\section{Results and discussion}

\subsection{Simultaneous removal of cadmium and copper (binary system)}

Figure 2 shows the concentration profiles of each heavy metals $(\mathrm{Cu}, \mathrm{Cd})$ at weight percent $(80 \% \mathrm{Cu}, 20 \% \mathrm{Cd})$ verses time. It was observed that the concentration of each heavy metals was declined with increasing of time. The final value of concentrations for cadmium and copper were 12 and $5 \mathrm{ppm}$ respectively at $40 \mathrm{~min}$. There is a clear difference between the decay rates of each metal (exponential decay with respect to copper and approximately linear decay with respect to cadmium). This behavior could be interpreted as follows: the large weight present of copper in addition to its more positive standard potential with respect of cadmium $\left(\mathrm{E}^{\mathrm{o}}=+0.34 \mathrm{~V}\right.$ (vs. SHE) for copper and $\mathrm{E}^{\mathrm{o}}=-0.4 \mathrm{~V}$ (vs. SHE) for cadmium) causes most of current goes to copper besides its surface concentration would approach to zero (mass transfer limitation) due to the high current value used in this work leading to an exponential decay of concentration. Similar behavior was observed by [31] during their studying on removal $(\mathrm{Cu}$ and $\mathrm{Cd})$ ions from 0.50 moldm $^{-3} \mathrm{Na}_{2} \mathrm{SO}_{4}$ at $\mathrm{pH} 2$ and $298 \mathrm{~K}$ using reticulated vitreous carbon (RVC) rotating cylinder electrode. However, the rates of decay concentration of cadmium and copper ions are same in their work due to the low concentrations of metals (56ppm Cd and $32 \mathrm{ppm} \mathrm{Cu}$ ). Similar decays in concentration of binary heavy metals was observed by [34] in their work for removal of copper and zinc using higher concentrations of them (500ppm).

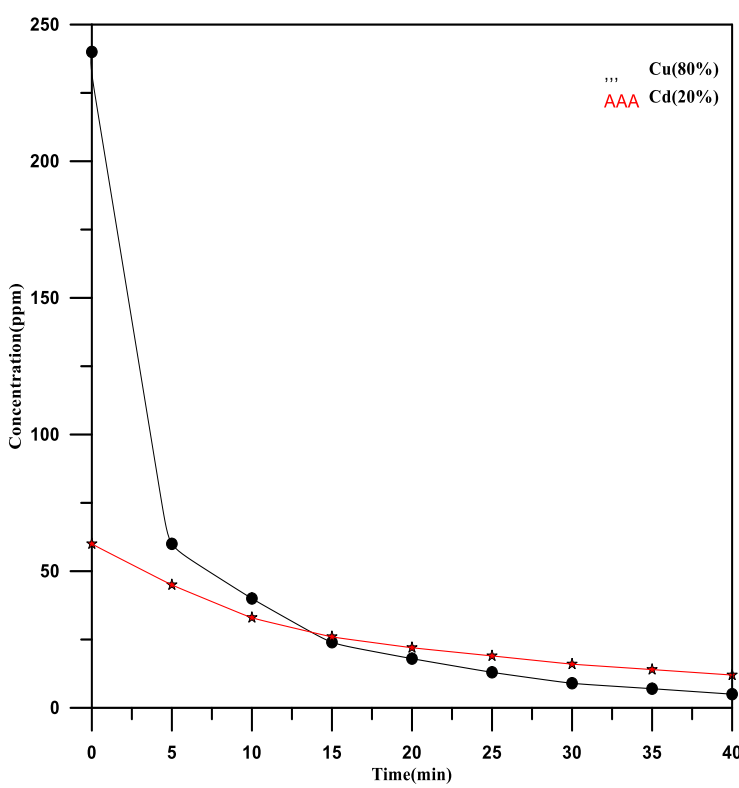

Figure 2: Concentration profiles verses time for $(80 \% \mathrm{Cu}, 20 \% \mathrm{Cd})$ mixture

Figure 3 displays the correspond relation between the removal efficiency and time for each metal. At $20 \mathrm{~min}$, the removal efficiency of Copper and cadmium were $92.5 \%$ and $63 \%$, respectively, then it increased as time increased to reach $97.7 \%$ and $80 \%$ respectively at the end of experiment (40 min). The results indicated that copper was removed faster than cadmium and approximately completed removal of copper was obtained while removal of cadmium not exceeded $80 \%$. This behavior was expected since the standard potential of cadmium is more negative than copper $\left(\mathrm{E}^{\mathrm{o}}=+0.34 \mathrm{~V}\right.$ (vs. SHE) for copper and $\mathrm{E}^{\mathrm{o}}=-0.4 \mathrm{~V}$ (vs. $\mathrm{SHE}$ ) for cadmium). It is well known, from electrochemistry principles, that the metal ion which has a standard reduction potential with more positive value can be easily reduced. Similar observation was found by [35] for potentiostatic removal of copper, cadmium and zinc at initial concentration of $10 \mathrm{ppm}$ for each metal using three dimensional reticulated vitreous carbon (RVC) electrode. Also similar trend was observed by [34] in their work for studying removal of copper and zinc from simulated binary metallic industrial wastewater using a packed-bed cathode. 


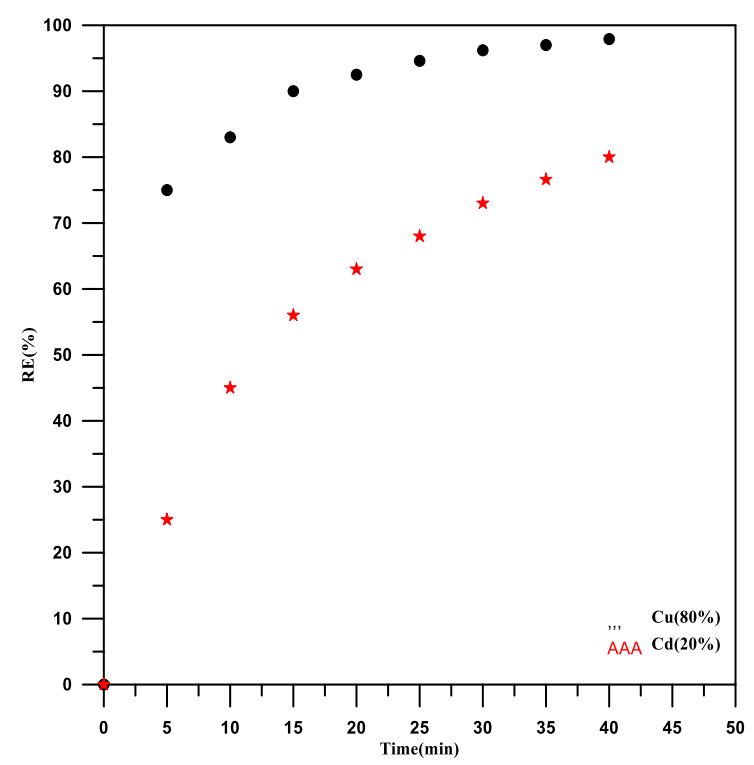

Figure 3: Removal efficiency verses time for $(80 \% \mathrm{Cu}, 20 \% \mathrm{Cd})$ mixture

Figure 4 displays the concentration profiles of each heavy metals $(\mathrm{Cu}, \mathrm{Cd})$ at weight percent $(60 \% \mathrm{Cu}, 40 \% \mathrm{Cd})$ verses time. It can be noted that the concentration of each heavy metals was declined with increasing of time. The final value of concentrations for cadmium and copper were 20 and $5 \mathrm{ppm}$ respectively at $40 \mathrm{~min}$. In comparison with Fig.2, it is clear that the final concentration of copper kept the same while the concentration of cadmium became higher. Figure 5 shows the correspond relation between the removal efficiency and time for each metal. At $20 \mathrm{~min}$, the removal efficiency of Copper and cadmium were $92.2 \%$ and $66.6 \%$, respectively, then it increased as time increased to reach $97.7 \%$ and $83 \%$ respectively at the end of run (40 min). It was clear that increasing $\mathrm{Cd}$ concentration and lowering $\mathrm{Cu}$ concentration have no significant effect on copper removal efficiency in comparison with Fig.3. This an indication that copper deposition is controlling step on the electrochemical deposition reaction at the present applied current (1.5A).

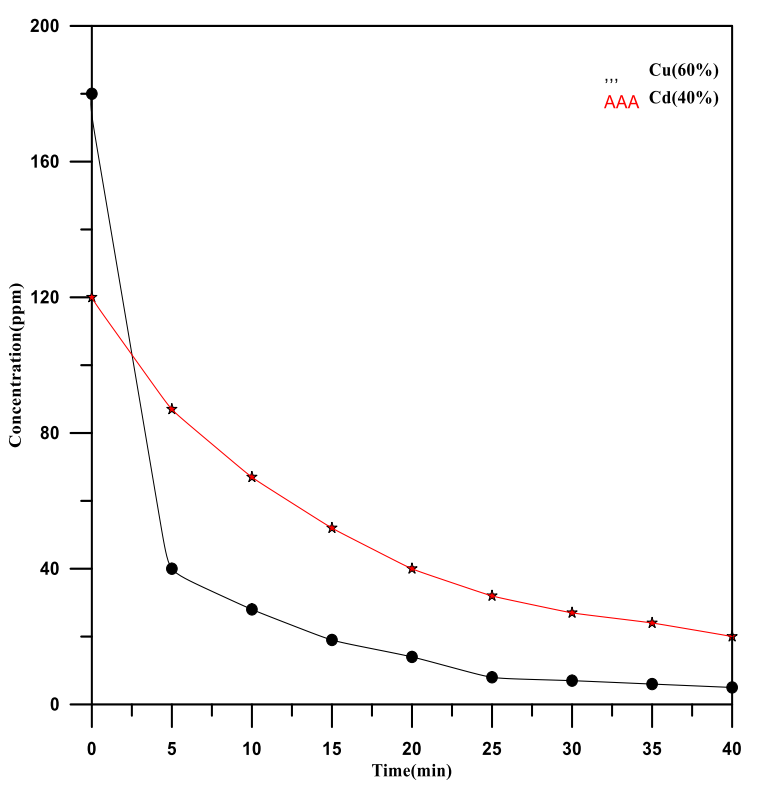

Figure 4: Concentration profiles verses time for $(60 \% \mathrm{Cu}, 40 \% \mathrm{Cd})$ mixture

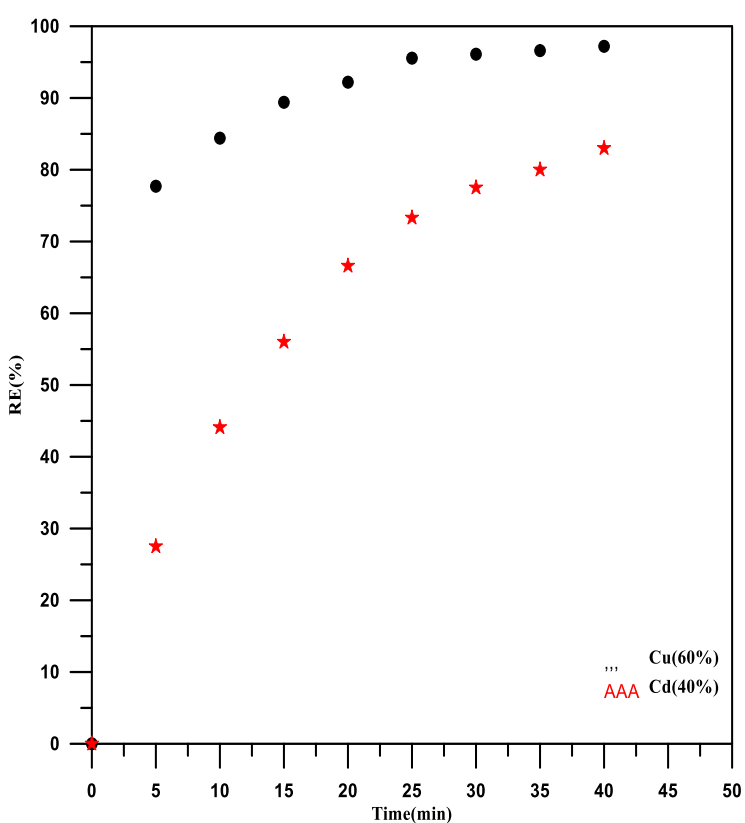

Figure 5: Removal efficiency vs. time for $(60 \% \mathrm{Cu}, 40 \% \mathrm{Cd})$ mixture

Figure 6 displays the concentration profiles of each heavy metals $(\mathrm{Cu}, \mathrm{Cd})$ at weight percent $(40 \% \mathrm{Cu}, 60 \% \mathrm{Cd})$ verses time. As can be seen, the concentration of each heavy metals was declined with increasing of time. The final value of the cadmium and copper concentrations were 25 and 6 ppm respectively at $40 \mathrm{~min}$. In comparison with figures (2 and 3 ), it is clear that the final concentration of copper kept approximately the same while the concentration of cadmium became higher. Figure 7 shows the correspond relation between the removal efficiency and time for each metal. At $20 \mathrm{~min}$, the removal efficiency of Copper 
and cadmium were $91.6 \%$ and $66 \%$, respectively, then it increased as the time increased to reach $95 \%$ and $86.11 \%$ respectively at the end of run $(40 \mathrm{~min})$. It can be seen that increasing $\mathrm{Cd}$ concentration and lowering $\mathrm{Cu}$ concentration tends to slightly decrease in copper removal efficiency and slightly increase of cadmium removal efficiency in comparison with Fig.3. However, copper deposition still the control reaction on the electrochemical deposition reaction within this range of concentrations.

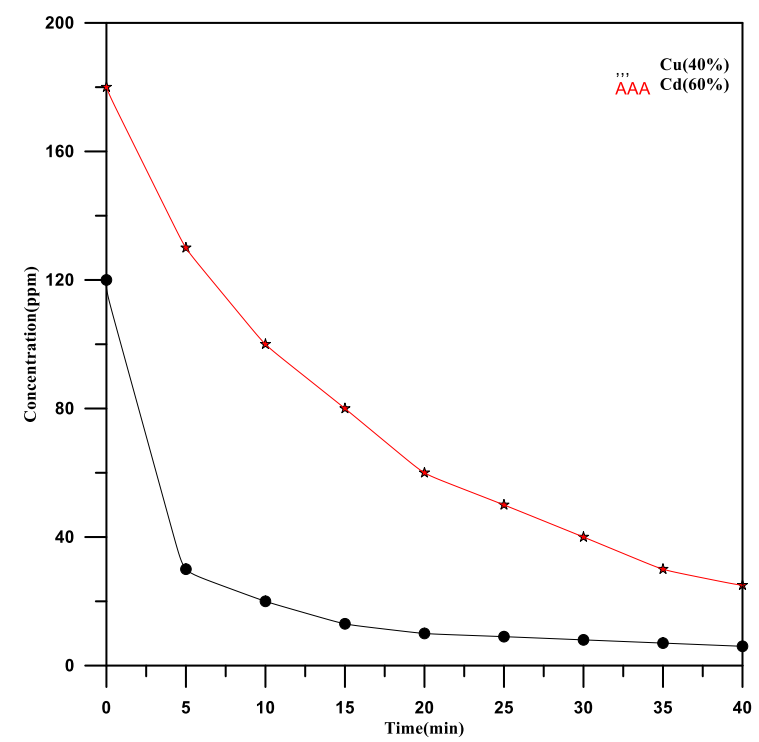

Figure 6: Concentration profiles verses time for $(40 \% \mathrm{Cu}, 60 \% \mathrm{Cd})$ mixture

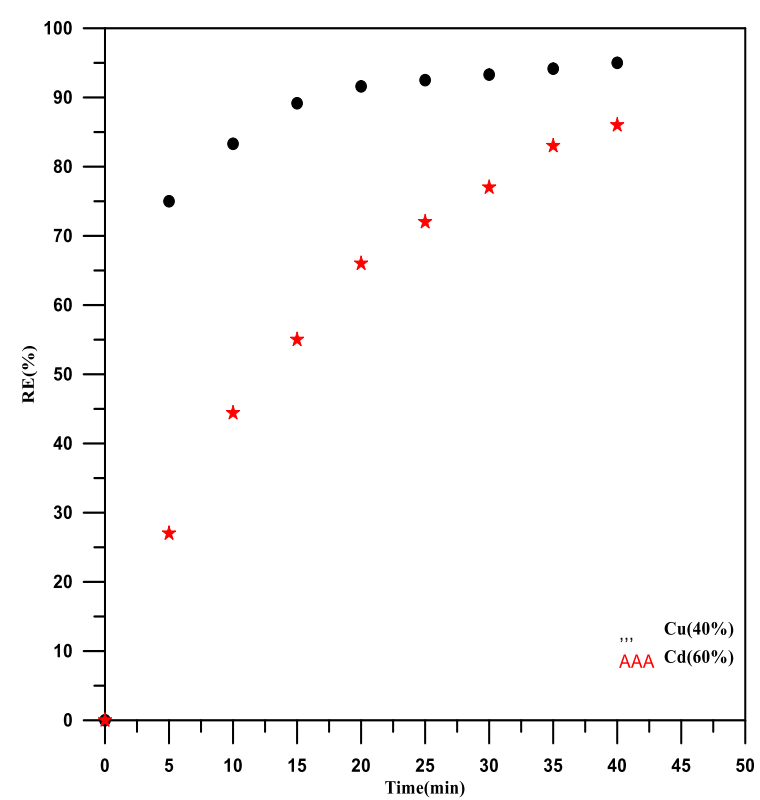

Figure 7. Removal efficiency verses time for $(40 \% \mathrm{Cu}, 60 \% \mathrm{Cd})$ mixture
Figure 8 demonstrates the concentration profiles of each heavy metals $(\mathrm{Cu}, \mathrm{Cd})$ at weight percent $(20 \% \mathrm{Cu}, 80 \% \mathrm{Cd})$ verses time. The data showed that the concentration of each heavy metals was declined with increasing of time. The final value of concentrations for cadmium and copper were 22 and $3 \mathrm{ppm}$ respectively at $40 \mathrm{~min}$. Results indicated that the final concentrations of copper and cadmium became slightly lower in comparison with Fig.6. Figure 9 shows the correspond relation between the removal efficiency and time for each metal. At 20 min, the removal efficiency of Copper and cadmium were $90 \%$ and $66 \%$, respectively, then it increased as the time increased to reach $93.5 \%$ and $88 \%$ respectively at the end of run (40 min). It was noted that increasing $\mathrm{Cd}$ concentration and lowering $\mathrm{Cu}$ concentration tends to a significant decrease of copper removal efficiency and a significant increase of cadmium removal efficiency in comparison with Fig.2. However, copper deposition still the control reaction on the electrochemical deposition reaction within this range of concentrations.

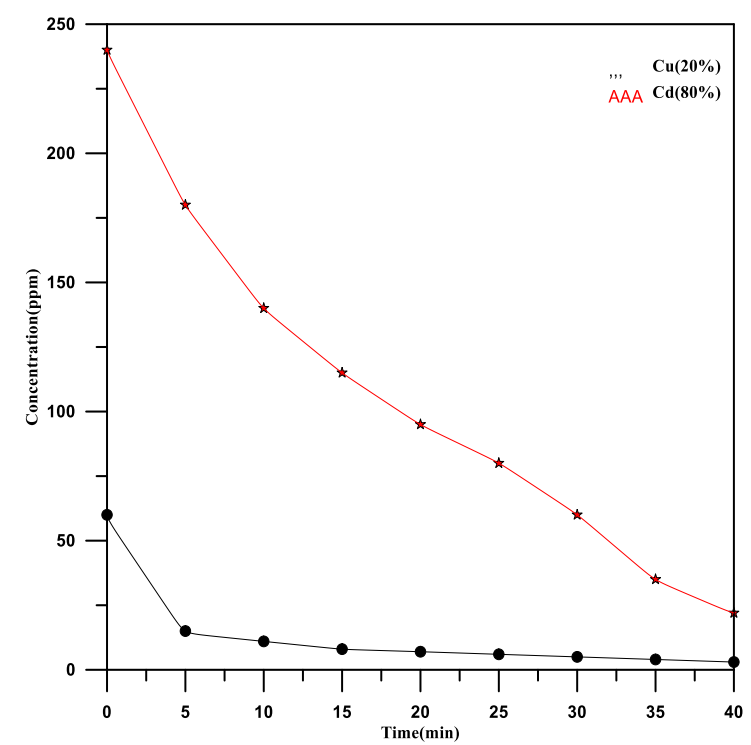

Figure 8: Concentration profiles verses time for $(20 \% \mathrm{Cu}, 80 \% \mathrm{Cd})$ mixtur 


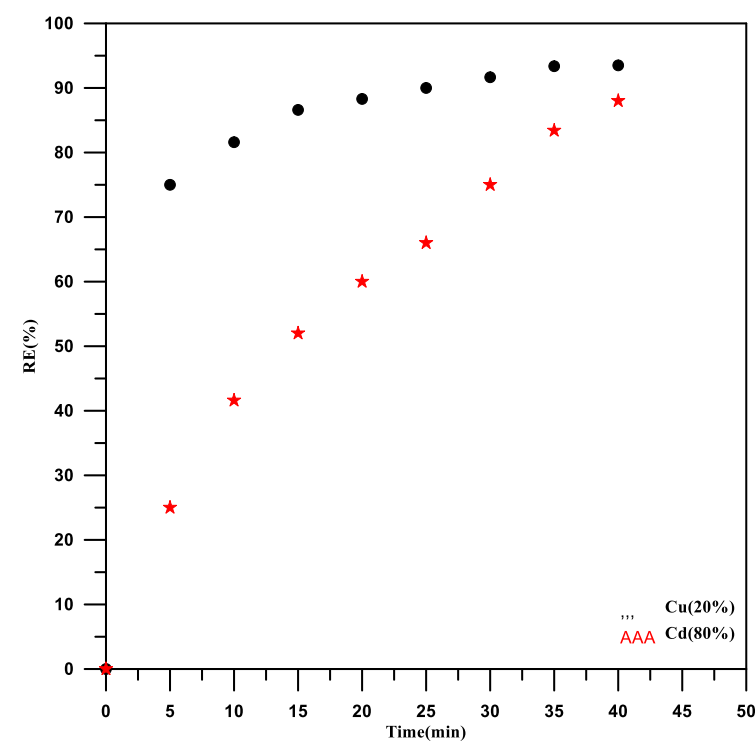

Figure 9: Removal efficiency verses time for $(20 \% \mathrm{Cu}, \mathbf{8 0} \% \mathrm{Cd})$ mixture

In order to confirm the impact of copper existing during cadmium removal, two further experiments were achieved on a monometallic $\mathrm{Cu}$ and $\mathrm{Cd}$ solutions under the same experimental conditions (current $1.5 \mathrm{~A}$, rotation speed $450 \mathrm{rpm}, \mathrm{pH}=2$, initial concentration 300ppm). The results are shown in Figures 10 and 11 respectively. The final concentration of copper alone at 40min was $2 \mathrm{ppm}$ with a removal efficiency of $99.3 \%$ while the final concentration of cadmium alone was $30 \mathrm{ppm}$ at the same time with a removal efficiency of $90 \%$.

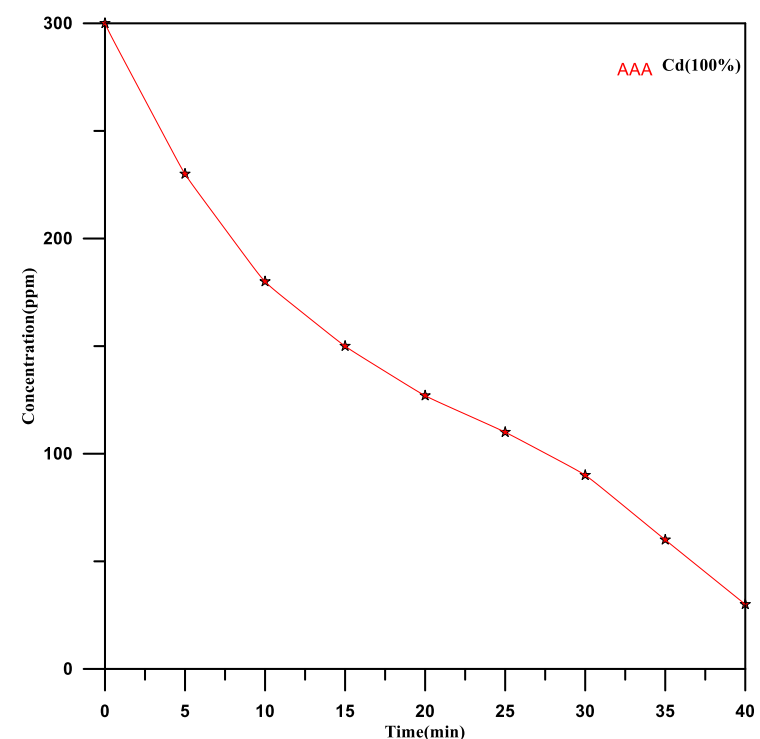

Figure 10: Concentration profile verses time for single metal (cadmium)

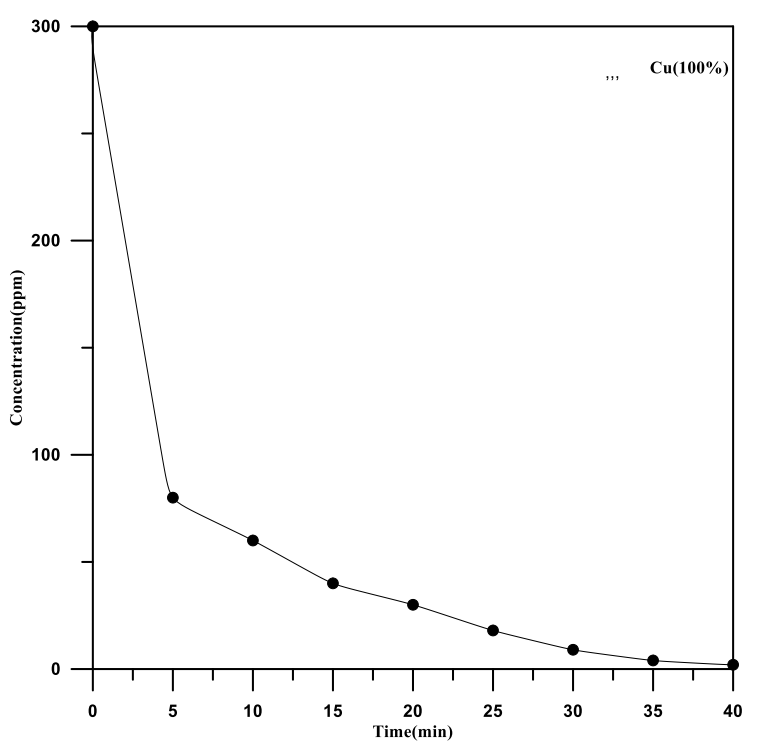

Figure 11: Concentration profile verses time for single metal (copper)

Figure 12 shows how the weight percent effects on the removal efficiency of each metal. The results showed that the removal efficiency of copper increased from $93.5 \%$ to $99.33 \%$ as its weight percent increased from $20 \%$ to $100 \%$. In a similar fashion, the removal efficiency of cadmium increased from $80 \%$ to $90 \%$ as its weight percent increased from $20 \%$ to100 \%. The results confirmed that the removal efficiency of any metals decreased in the presence of the other metal. However, this effect is strong in case of metal with more negative standard potential $(\mathrm{Cd})$. Similar observations were found by [34] in their work for the removal of copper and zinc. However, selective separation of copper was happened in their work due to the large deference in the standard potential of copper and zinc $\left(\mathrm{E}^{\mathrm{o}}=+0.34 \mathrm{~V}\right.$ (vs. SHE) for copper and $E^{\circ}=-0.762 \mathrm{~V}$ (vs. SHE) for zinc), even though the real values are dependent on the actual two metals concentrations. 


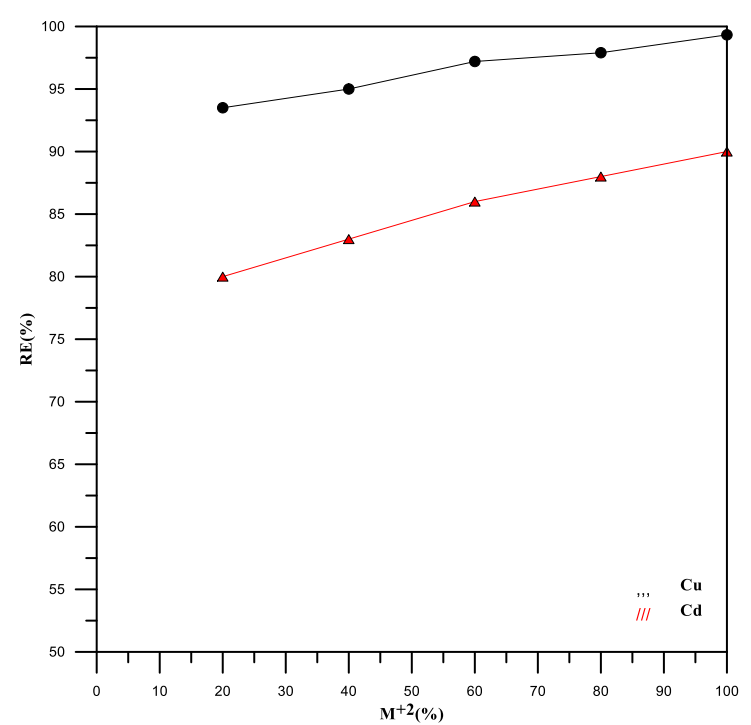

Figure 12: Removal efficiency verses heavy metal weight percent in the binary system

\subsection{Current efficiency}

\subsubsection{Theoretical}

The effectiveness of any electrodeposition process can be evaluated by computing of current efficiency or faradaic efficiency. For the process including heavy metals, side reaction is significantly effect of the current efficiency. However in the case of side reaction is hydrogen evolution, the process is environmentally benefit since hydrogen can be utilized as a renewable energy. All the cathodic reactions should be taken into account when estimating the cathodic current efficiency for any removal process. For the cathodic reduction of one or more heavy metals, the following equation can be written for the metal $\mathrm{M}_{\mathrm{i}}$ :

$M_{i}^{Z i+}(a q)+Z_{i} \rightarrow M_{i}(s)$

Where

i may be taken values from 1 to $\mathrm{N}$.

$\mathrm{Z}_{\mathrm{i}}$ : is the number of moles of electrons contributing in the reaction.

If $n_{i}$ moles of positive ions were reduced, the theoretical amount of the required electricity is:

$Q_{t h}=F \times \sum_{i=1}^{N} n_{i} Z_{i}$

where F is Faraday's constant; 96,485 coulomb/mole.

In the case of using a batch electrochemical reactor for removing of heavy metals from a solution of $\mathrm{V}(\mathrm{L})$ having initial concentration $\mathrm{C}_{\mathrm{o}}$, the number of moles of the any ion to be removed is:
$n_{i}=\frac{V\left(C_{o}-C_{i}\right)}{M_{i}}$

Where $\mathrm{M}$ is the molar mass of species $\mathrm{i}$; $\mathrm{g} /$ mole. (For $\mathrm{Cu}=63.546$ and for $\mathrm{Cd}=112.411 \mathrm{~g} / \mathrm{mol}$ )

The actual quantity of electricity used to affect reduction reactions is:

$Q_{a c t}=I \times t$

Where; $\mathrm{I}$ is the applied current (A), and $\mathrm{t}$ is the electrolysis time (s).

The percent current efficiency, (C E \%), is then estimated as follows:

$C E(\%)=\frac{Q_{t h}}{Q_{a c t}} \times 100$

For mixed metals removal, the current efficiency can be calculated as follows [34]:

CE $(\%)$ of metals $=$
$\frac{F \times V \times\left\{\left[\frac{Z\left(C_{o}-C_{i}\right)}{M}\right]_{C u}+\left[\frac{z\left(C_{o}-C_{i}\right)}{M}\right]_{C d}\right\}}{I \times t} \times 100$

\subsubsection{Effect of $\mathrm{Cu}$ and $\mathrm{Cd}$ weight percent}

Figure 13 shows that the current efficiency of metal removal decreased with increasing of electrolysis time and with increasing of $\mathrm{Cd}$ weight percent or decreasing $\mathrm{Cu}$ weight percent. Current efficiency is always higher at the initial stage of electrolysis and then declined with increasing time for all weight percent of metals. These observations revealed that the main reason for the declining current efficiency is the hydrogen evolution during the initial periods of electrolysis. However, there are other reasons that caused the decline in the current efficiency in the later stages of electrolyyis [34]. The passage of the applied electric current through the cell resistance (IR drop) is one of reasons that causing loss of current efficiency. This loss was seemed when the temperature of electrolysis increased with the progress of electrolysis. In all experiments performed at 1.5 A. however, the rise in temperature did not exceed 5 ${ }^{\circ} \mathrm{C}$ during the electrolysis; therefore the IR drop couldn't consider as a major factor.

The relation between current efficiency and weight percent of cadmium is shown in figure ( 54 . where increasing the weight percent resulted in decreasing the current efficiency since the participation of copper is lowered in addition to the main effect of hydrogen. The Current efficiency was $11.06 \%$ at $20 \% \mathrm{Cd}$ then decreased to $5.15 \%$ at $100 \% \mathrm{Cd}$. Figure 15 shows how the current efficiency affected by weight percent of copper where it was increased from $7.6 \%$ at weight percent of copper $20 \%$ to $12.56 \%$ at $100 \% \mathrm{Cu}$. Generally, 
hydrogen evolution considers as the main affected parameter on the current efficiency. Similar observations were found by Alebrahim et al., 2017.

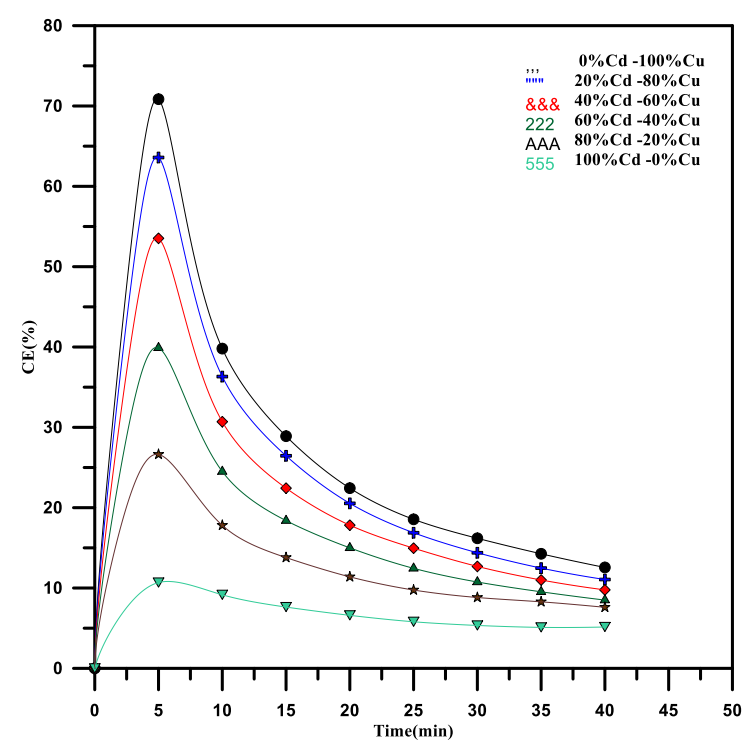

Figure 13: Current efficiency verse time at different weight percent of Copper and Cadmium

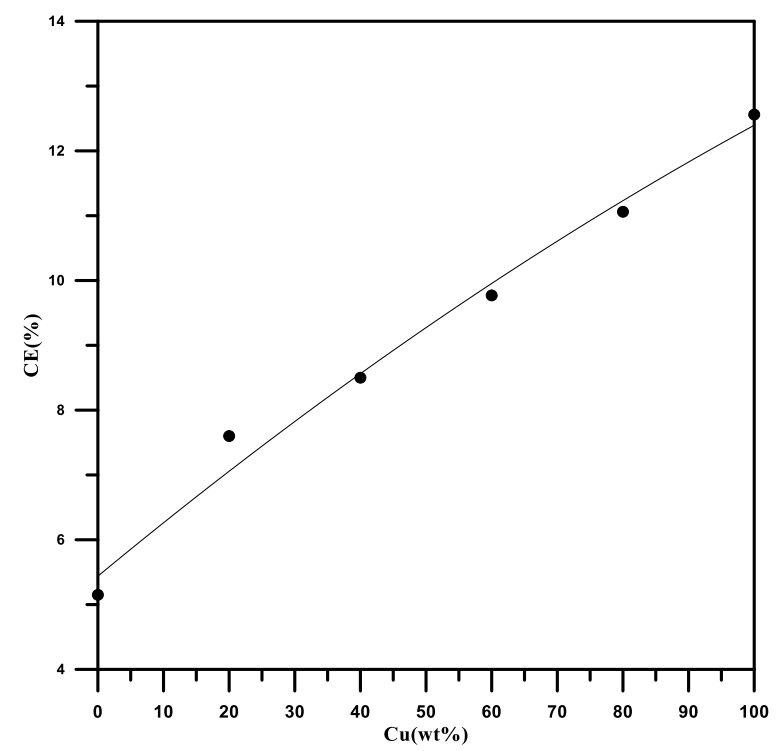

Figure 14: The current efficiency verses the weight percent of copper

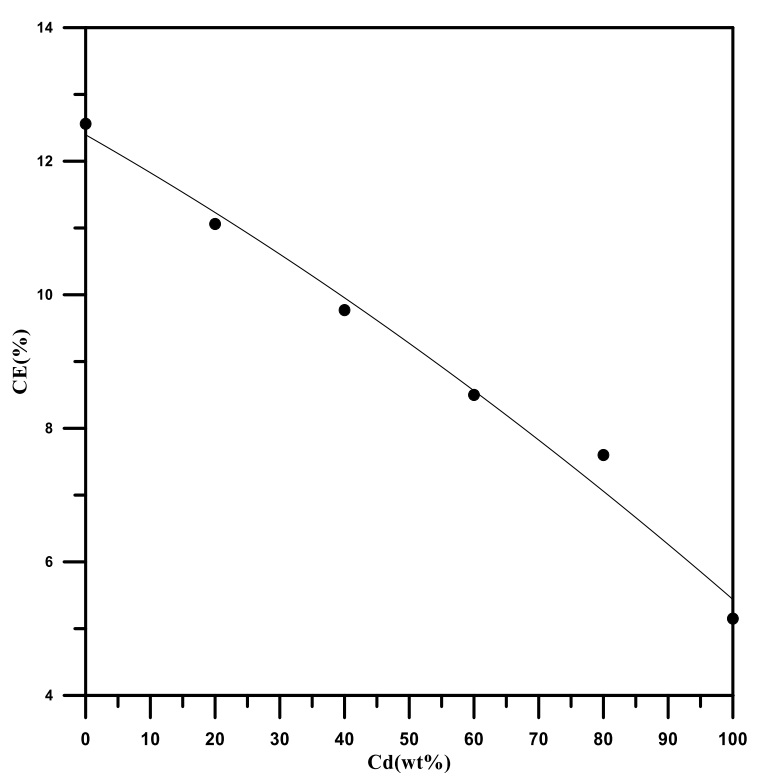

Figure 15: The current efficiency verses the weight percent of cadmium

\section{Conclusions}

The simultaneous removal of binary system (copper and cadmium) was achieved successfully using rotating tubular packed bed of woven screens electrode. The results showed that, in the presence of cadmium, removal efficiency of copper increased with increasing its weight present. Similar trend was noted in the case of cadmium in the presence of copper. The results revealed that current efficiency is higher at the initial stage of electrolysis then declined with the progress of time. Increasing the weight present of cadmium led to decrease the current efficiency. Opposite behavior was noted in the case of copper. In spite of the low current efficiency due to the effect of side reaction (hydrogen evolution), the process is environmentally benefit since hydrogen can be utilized as a renewable energy. The present study revealed the copper electrodeposition reaction is the control step in the removal of binary system (copper and cadmium) due to the more positive value of standard potential of copper in comparison with cadmium and the present applied current that given more negative cathode potential.

\section{ACKNOWLEDGEMENTS}

The authors wish to acknowledge the helpful and technical assistance given by the staff of Chemical Engineering Department, College of EngineeringUniversity of Al-Qadisiyah.

\section{Reference}

[1] Wuana, R. A., Okieimen, F. E., (2011), "Heavy metals in contaminated soils: a review of sources, 
chemistry, risks and best available strategies for remediation”, ISRN Ecology, 2011: 1-20.

[2] Sheng, P. X., Ting, Y. P., Chen, J. P., \& Hong, L., (2004), "Sorption of lead, copper, cadmium, zinc, and nickel by marine algal biomass: characterization of biosorptive capacity and investigation of mechanisms", Journal of colloid and interface science, 275(1), 131-141.

[3] Yu, B., Zhang, Y., Shukla, A., Shukla, S. S., \& Dorris, K. L. (2000), "The removal of heavy metal from aqueous solutions by sawdust adsorptionremoval of copper", Journal of Hazardous Materials, 80(1-3), 33-42.

[4] Rao, M. M., Ramesh, A., Rao, G. P. C., \& Seshaiah, K., (2006), "Removal of copper and cadmium from the aqueous solutions by activated carbon derived from Ceiba pentandra hulls", Journal of hazardous materials, 129(1-3), 123-129.

[5] Fato, F. P., Li, D. W., Zhao, L. J., Qiu, K., \& Long, Y. T., (2019), "Simultaneous Removal of Multiple Heavy Metal Ions from River Water Using Ultrafine Mesoporous Magnetite Nanoparticles", ACS Omega, 4(4), 7543-7549.

[6] Esalah, J. O., Weber, M. E., \& Vera, J. H., (2000), "Removal of lead, cadmium and zinc from aqueous solutions by precipitation with sodium $\mathrm{Di}$ (n-octyl) phosphinate", The Canadian Journal of Chemical Engineering, 78(5), 948-954.

[7] Ravindran, V., Stevens, M. R., Badriyha, B. N., \& Pirbazari, M., (1999), “ Modeling the sorption of toxic metals on chelant-impregnated adsorbent", AIChE journal, 45(5), 1135-1146.

[8] Toles, C. A., \& Marshall, W. E., (2002), “ Copper ion removal by almond shell carbons and commercial carbons: batch and column studies", Separation science and technology, 37(10), 23692383.

[9] Zouboulis, A. I., Matis, K. A., Lanara, B. G., \& Loos-Neskovic, C., (1997), “ Removal of cadmium from dilute solutions by hydroxyapatite. II. Flotation studies", Separation Science and Technology, 32(10), 1755-1767.

[10] Canet, L., Ilpide, M., \& Seta, P., (2002), “ Efficient facilitated transport of lead, cadmium, zinc, and silver across a flat-sheet-supported liquid membrane mediated by lasalocid A", Separation Science and Technology, 37(8), 1851-1860.

[11] Eccles, H., (1999), "Treatment of metalcontaminated wastes: why select a biological process?", Trends in biotechnology, 17(12), 462465.

[12] Fu, F., \& Wang, Q., (2011), "Removal of heavy metal ions from wastewaters: a review", Journal of environmental management, 92(3), 407418.

[13] Juttner, K., Galla, U., \& Schmieder, H., (2000), "Electrochemical approaches to environmental problems in the process industry", Electrochimica Acta, 45(15-16), 2575-2594.

[14] Pletcher, D., Walsh, F. C., (1990), “ Industrial Electrochemistry", Chapman and Hall, New York.

[15] AlJaberi, F. Y., \& Mohammed, W. T. (2018), "The Most Practical Treatment Methods for Wastewaters: A Systematic Review", Mesop. Environ. J., 5(1), 1-18.

[16] Tonini, G. A., Martins Farinos, R., de Almeida Prado, P. F., \& Martins Ruotolo, L. A., (2013), "Box-Behnken factorial design study of the variables affecting metal electrodeposition in membraneless fluidized bed electrodes", Journal of Chemical Technology \& Biotechnology, 88(5), 800-807.

[17] Yaqub, A., Ajab, H., Khan, S., Khan, S., \& Farooq, R., (2009), "Electrochemical removal of copper and lead from industrial wastewater: mass transport enhancement", Water Quality Research Journal, 44(2), 183-188.

[18] Chang, S. H., Wang, K. S., Hu, P. I., \& Lui, I. C., (2009), “ Rapid recovery of dilute copper from a simulated $\mathrm{Cu}-\mathrm{SDS}$ solution with low-cost steel wool cathode reactor", Journal of hazardous materials, 163(2-3), 544-549.

[19] Chellammal, S., Raghu, S., Kalaiselvi, P., \& Subramanian, G., (2010), "Electrolytic recovery of dilute copper from a mixed industrial effluent of high strength COD", Journal of hazardous materials, 180(1-3), 91-97.

[20] Basha, C. A., Saravanathamizhan, R., Nandakumar, V., Chitra, K., \& Lee, C. W., (2013), "Copper recovery and simultaneous COD removal 
from copper phthalocyanine dye effluent using bipolar disc reactor", Chemical Engineering Research and Design, 91(3), 552-559.

[21] Khattab, I.A., Shaffei, M.F., Shaaban, N.A., Hussein, H.S., Abd El-Rehim, S.S., (2013a), "Electrochemical removal of copper ions from dilute solutions using packed bed electrode. Part I", Egyptian Journal of Petroleum 22, 199-203.

[22] Khattab, I.A., Shaffei, M.F., Shaaban, N.A., Hussein, H.S., Abd El-Rehim, S.S. ,(2013b), "Electrochemical removal of copper ions from dilute solutions using packed bed electrode. Part II”, Egyptian Journal of Petroleum 22, 205-210.

[23] de Lourdes Llovera-Hernández, M., ÁlvarezGallegos, A., Hernández, J. A., \& Silva-Martínez, S., (2016), " Cadmium removal from dilute aqueous solutions under galvanostatic mode in a flowthrough cell", Desalination and Water Treatment, 57(48-49), 22809-22817.

[24] Sulaymon, A. H., Mohammed, S. A., \& Abbar, A. H., (2017), " Cadmium removal from simulated chloride wastewater using a novel flow-by fixed bed electrochemical reactor: Taguchi approach", Desalination Water Treat., 74, 197-206.

[25] Walsh, F. C., (1992), "The role of the rotating cylinder electrode reactor in metal ion removal", Electrochemistry for a cleaner environment, 101159.

[26] Gabe, D. R., (1974), "The rotating cylinder electrode", Journal of Applied Electrochemistry, 4(2), 91-108.

[27] Abdel-Aziz, M. H., Nirdosh, I., \& Sedahmed, G. H., (2015), "Mass transfer at a rotating tubular packed bed of woven screens in relation to electrochemical and catalytic reactor design", International Journal of Heat and Mass Transfer, 90, 427-438.

[28] Sioda, R. E., (1976), "Mass transfer problems in electrolysis with flowing solution on single and stacked screens", Journal of Electroanalytical Chemistry and Interfacial Electrochemistry, 70(1), 49-54.

[29] Green, D., Perry, R., (2008), "Perry's Chemical Engineers' Handbook, 8thed”, McGrawHill, New York.
[30] Ayres, D. M., Davis, A. P., \& Gietka, P. M. (1994), “ Removing heavy metals from wastewater", Engineering Research Centre Report, 90.

[31] Reade, G. W., Nahle, A. H., Bond, P., Friedrich, J. M., \& Walsh, F. C., (2004), "Removal of cupric ions from acidic sulfate solution using reticulated vitreous carbon rotating cylinder electrodes", Journal of Chemical Technology \& Biotechnology: International Research in Process, Environmental \& Clean Technology, 79(9), 935945.

[32] Grau, J. M., \& Bisang, J. M. (2009), "Retracted: Effluent treatment using a bipolar electrochemical reactor with rotating cylinder electrodes of woven-wire meshes", Journal of Chemical Technology \& Biotechnology: International Research in Process, Environmental \& Clean Technology, 84(7).

[33] Hemeidan J. H. and Abbar, A. H. (2019), "Electrochemical removal of copper from a simulated wastewater using a rotating tubular packed bed of woven screens electrode", AlQadisiyah Journal for Engineering Sciences, 12(2), 127-134.

[34] Alebrahim, M. F., Khattab, I. A., Cai, Q., \& Sanduk, M., (2017), "Practical study on the electrochemical simultaneous removal of copper and zinc from simulated binary-metallic industrial wastewater using a packed-bed cathode", Egyptian journal of petroleum, 26(2), 225-234.

[35] Walsh, F. C., (2001), "Electrochemical technology for environmental treatment and clean energy conversion", Pure and applied chemistry, 73(12), 1819-1837. 